5. Keretsman A., Palko A. Analiz stanu zdorovia studentiv-medykiv u zalezhnosti vid biolohichnykhfaktoriv i sposobu zhyttia protiahom 2010 - 2012 rokiv Naukovyi visnyk Uzhhorodskoho universytetu, seriia "Medytsyna", vypusk 1 (46), 2013 r. S. 162-166.

6. Kryvosheieva H. Formuvannia kultury zdorovia studentiv universytetu: avtoref.dys. na zdobuttia nauk. stupenia kand. ped. nauk: spets. 13.00.04 "Teoriia i metodyka profesiinoi osvity". -Luhansk, $2001.20 \mathrm{~s}$.

7. Makarenko V. Kultura zdorovia kak pryorytetnaia zadacha obshchestvennoho razvytyia molodezhy / V.K. Makarenko, O.D. Hryhoreva, Zh.V. Toma // Sportyvnyii psykholoh. - 2009. №2 (17). S. 63 67.

8. Prystupa E. Pedahohycheskaia dyahnostyka lychnostnoho sotsyalnoho zdorovia rebënka. URL: http://www.psyh.kiev.ua (data zvernennia 29.10.2019)

9. Sokolova T. Zdorove naselenyia v sotsyalnom kontekste (na prymere rabotnykov DVZhD) : avtoref. dys. ... kand. sotsyol. nauk. - Khabarovsk, 2005. $20 \mathrm{~s}$.

10. Usmanov $\mathrm{Y}$. Zdorove molodezhy kak obshchestvennaia tsennost $\mathrm{v}$ sovremennom rossyiskom obshchestve (sotsyalno-fylosofskyi analyz): avtoref. dys. na soyskanye uchen. stepeny fylosof. ped. nauk:spets. 09.00.11 "Sotsyalnaia fylosofyia". - Ufa, 2008. $20 \mathrm{~s}$.

11. Ushakov Y. Sovremennyie problemyi kachestva zhyzny studentov / Hyhyena y sanytaryia. - 2007. №2. S. $56-58$.

12. Ushakova Ya. Zdorove studentov y faktoru eho formyrovanyia / Vestnyk nyzhehorodskoho unyversyteta. -2007 . №4. S. $197-202$.

Одержано статтю: 10.10 .2019

Прийнято до друку: 25.10.2019

УДК 377: 37.011

DOI: $10.15330 /$ esu. $1.52-58$

\section{Галина Борин,}

кандидат педагогічних наук, доцент, ДВНЗ "Прикарпатський національний університет імені Василя Стефаника" (м. Івано-Франківськ, Україна)

Galyna Boryn,

Candidate of pedagogical sciences (PhD), Associate Professor, Vasyl Stefanyk Precarpathian National university (Ivano-Frankivsk, Ukraine)

boryngv@ukr.net

\title{
ДІЯЛЬНІСНИЙ ПІДХІД У ПРОФЕСІЙНІЙ ПІДГОТОВЦІ МАЙБУТНІХ ПЕДАГОГІВ ДО ТВОРЧОЇ ХУДОЖНЬО-КОНСТРУКТИВНОЇ ДІЯЛЬНОСТІ 3 ДІТЬМИ ДОШКІЛЬНОГО ВІКУ
}

\section{ACTUAL APPROACH IN PROFESSIONAL TRAINING OF FUTURE TEACHERS TO CREATIVE ARTISTIC AND CONSTRUCTIVE ACTIVITY WITH CHILDREN OF PRESCHOOL AGE}

У статті проаналізовано актуальні погляди на професійну підготовку майбутніх педагогів дошкільних закладів освіти. Виокремлено основні напрями удосконалення підготовки студентів спеціальності “Доикільна освіта" в контексті художньоконструктивної діяльності вихованців. Охарактеризовано особливості художньоконструктивної діяльності дітей доикільного віку та окреслено зміст та напрями підготовки майбутніх педагогів в означеному напрямі на основі діяльнісного підходу.

Ключові слова: художньо-конструктивна діяльність, розвиток, підготовка майбутніх вихователів, творчість, дитина, педагог.

The article analyzes actual views on the future teachers' professional training of preschool educational institutions. The basic directions of improvement of training of future students of specialty "Preschool education" in the context of artistic and constructive activity of pupils are 
singled out. The peculiarities of artistic and constructive activity of preschool children are described and the content and directions of future teachers' training in the outlined direction based on the activity approach are outlined.

The necessity of forming of future teacher's creative personality as a significant factor of development of pupils' creative abilities is substantiated. At the same time, it is emphasized that the positive, interested attitude of the teacher to children's creativity as a unique phenomenon plays an important role in this process. An educator who believes in the capabilities of his or her pupils, monitors the dynamics of development of their creative abilities, thoughtfully analyzes the products of children's creativity, can count on success in the direction of artistic and constructive activity of children. The main attention is paid to the fact that future educators should realize when teaching at a higher educational institution that in order to organize children's creative activity it is necessary to create conditions under which the preschooler's creative abilities are formed during creative activity, since during the production of a specific product the child poses purpose and achieves concrete results. At the same time she can choose what to make, what materials, what method of manufacture to choose.

The peculiarities of active approach application in the educational process of IHE by modeling forms of artistic and constructive activity are analyzed, discussing problematic issues, involving students in creative artistic and constructive activity during which they prepare to familiarize children with the properties of the material, the structure of products, features and stages of their production.

Key words: artistic and constructive activity, development, training of future educators, creativity, child, teacher.

Постановка проблеми. Творча особистість майбутнього педагога - вагомий чинник розвитку творчих здібностей вихованців. Важливу роль в цьому процесі відіграє позитивне, зацікавлене ставлення педагога до дитячої творчості як унікального явища [1]. Вихователь, який вірить у можливості своїх вихованців, слідкує за динамікою розвитку їхніх творчих здібностей, вдумливо аналізує продукти дитячої творчості, може розраховувати на успіх у керівництві художньоконструктивною діяльністю дітей. Формування майбутньої творчої особистості $\epsilon$ неможливим без кваліфікованого фахівця. Тому проблема підготовки майбутніх педагогів до художньо-конструктивної діяльності в умовах закладу дошкільної освіти є значущою. Ми погоджуємось 3 думкою О. Вишневського [3] стосовно того, шо система освіти вимагатиме від вихователя закладу дошкільної освіти інших педагогічних поглядів та способів діяльності. За умов сучасного мінливого освітнього простору варто подумати про те, що фахівцю потрібно бути людиною “знаючою" та "діяльною". Тому підготовку майбутніх педагогів варто будувати на засадах навчання студента в діяльності і через діяльність. Такий підхід полягає в тому, що саме активна діяльність студента (дитини) є “рушійною силою розвитку, $\mathrm{i}$ на кожному етапі існує провідна діяльність, яка найбільше сприяє розвиткові особистості в певний період онтогенезу" [7, с. 88].

Аналіз останніх досліджень і публікацій. Особливості застосування діяльнісного підходу у професійній підготовці майбутніх педагогів досліджено у науковому доробку О. Абдуліної, О. Вишневського, А. Капської, Н. Лисенко, О. Пєхоти, В. Рибалко, В. Сєрікова, О. Якси тощо. Проблемі творчої художньо-конструктивної діяльності дітей дошкільного віку присвячено дослідження Н. Ветлугіної, Н. Голоти, В. Котляра, В. Кардашова, Н. Сакуліної, О. Сухорукової та ін. Зокрема ученими доведено, що під час своєї творчої діяльності дитина не пасивно копіює довкілля, а перетворює його відповідно до наявного власного життєвого досвіду і особистісного ставлення до зображуваного. Розвиток творчих здібностей дошкільника учені 
пов'язують 3 діяльністю, тобто 3 організацією навчання, оскільки під час виготовлення конкретного виробу дитина входить в процес, за якого навчається ставити мету і досягати конкретних результатів. При цьому вона може сама обирати, що їй виготовляти, з яких матеріалів, який спосіб обрати, що, в свою чергу, сприяє іï активному творчому розвитку. Майбутній педагог повинен бути готовим до включення вихованців в активну творчу діяльність.

Метою статті $€$ виокремлення основних напрямів удосконалення підготовки майбутніх педагогів до творчої художньо-конструктивної діяльності 3 дітьми дошкільного віку. Перед нами постають такі завдання: охарактеризувати особливості художньо-конструктивної діяльності дітей дошкільного віку та окреслити зміст та засоби підготовки майбутніх педагогів в означеному напрямі на основі діяльнісного підходу.

Виклад основного матеріалу. Загальновідомо, що професійні якості та, зокрема, і схильність до творчості у майбутнього педагога формуються лише у діяльності. Підтвердження цьому знаходимо у дослідженнях Н. Якси, яка стверджує, шо "навчити людину плавати можна лише у воді, а навчити людину діяти можна лише у діяльності. Людина виступає в житті перш за все як діяч, митець, творець, незалежно від того, яким видом діяльності вона займається" [7, с. 43].

Під діяльністю розуміють “систему усвідомлених рухів, дій, зусиль, скерованих на осягнення певної мети” [3, с. 29]. Термін “діяльність” визначають як праця, робота, активність, поведінка, спосіб активного “відношення суб'єкта (людини) до світу, спрямований на його ціле відповідне перетворення та зміну” [7, с. 43]; це “внутрішня (психічна) і зовнішня (фізична) активність людини, яка регулюється усвідомленою метою. Діяльність нерозривно пов'язана з пізнанням і волею, спирається на них" [6, с. 54].

Неабияку роль у підготовці майбутніх педагогів відіграє викладач закладу вищої освіти. Якщо він прагне “виховати у студентів справжні творчі нахили, повинен мати у своєму педагогічному арсеналі широкий набір прийомів, які б спонукали до творчих пошуків... Досвідчений педагог нерідко проводить заняття так, що у студента створюється враження, начебто він сам пришов до певної ідеї. Студент не помічає “підказки" викладача, він переконаний, що може й сам дійти певної думки, створити власне трактування" [4, с. 11]. При цьому О. Вишневський наголошує, діяльність студента має бути "його діяльністю, націленою на його потреби, ним спланованою, ним виконуваною, і він має бути “власником" та оцінювачем одержаного результату" [3, с. 30]. Тому свою роботу в означеному ми спрямовуємо на розвиток діяльнісних можливостей студента, оскільки він ніколи і нікому не буде переказувати зміст знань, які отримав у 3ВО, а буде використовувати їх у своїй майбутній професійній діяльності під час взаємодії з дітьми.

Майбутніх педагог готується до самореалізації саме в педагогічній діяльності. Ïї учені трактують як “складний, багатоаспектний, надзвичайно динамічний процес, який здійснюється за умов, що постійно змінюються, з урахуванням вікових та індивідуальних особливостей дітей та особистості педагога" [7, с. 45]. Діяльнісний підхід у професійній підготовці майбутніх вихователів $є$ науковим методологічним принципом та грунтується на урахуванні єдності процесів викладання і учіння, які функціонують у нероздільній єдності і розглядає “провідні механізми формування та розвитку особистості шляхом проектування конструювання, організації i управління процесом людської діяльності" [6, с. 22]. 
Задля розвитку творчості дітей дошкільного віку майбутній вихователь повинен бути готовим до створення в закладі дошкільної освіти відповідного моральнопсихологічного клімату, необхідного для успішної художньо-конструктивної діяльності вихованців. Таку атмосферу творять із зацікавленого ставлення педагога до освітнього процесу, побудованого на творчій взаємодії вихователя та дітей, урахуванні їх індивідуальних можливостей, забезпеченні відчуття успіху в творчій діяльності, оскільки педагогіка ставить собі за мету “удосконалення діяльності педагога та вихованця і входить до групи наук, зв'язок яких 3 діяльністю вказує на їх наближеність до мистецтва, бо діяльність часто прагне до досконалості. Але воно - мистецтво - є лише “додатком", який вказує на якість діяльності у цій сфері $[5$, c. 6].

У процесі роботи над практичними завданнями студентам варто усвідомити, що проблема розвитку творчості дитини є складною, багатоаспектною, а художньоконструктивна діяльність дошкільника має чималий позитивний вплив на формування та розвиток майбутньої особистості, становленню дружніх стосунків у колективі дітей; формує відчуття відповідальності, взаємодопомоги; сприяє розвитку психічних процесів: уяви та фантазіі, уваги, мислення, пам'яті; виховує працелюбність, формує естетичний смак, відчуття прекрасного, допомагає самоствердитись у власній творчій діяльності.

Під час застосування діяльного підходу в освітньому процесі ЗВО шляхом моделювання форм художньо-конструктивної діяльності, студенти готуються до ознайомлення дітей 3 особливостями матеріалу для конструювання. У процесі розв'язання завдань проблемного характеру під час виготовлення виробів розвивається пошукова діяльність: вони можуть “винаходити" прийоми, способи дій на основі наявного в них досвіду. Окрім того, такий вид діяльності розвиває: конструктивне мислення, творчу уяву, художній смак; стимулює розвиток пам'яті; активізує розумові процеси; словник збагачується спеціальними термінами; сприяє активізації розумової та творчої навчальної діяльності; забезпечує в подальшому результативну спільну діяльність педагога і дитини.

Формуванню творчості передують набуття знань та умінь у майбутніх педагогів. Нормативна навчальна дисципліна "Художня праця та основи дизайну" має на меті розкриття змісту, форм і засобів оволодіння студентами практичними художньо-конструктивними уміннями та навичками, необхідними для вирішення творчих завдань (згідно сучасних вимог до проведення заняття та підготовки вихователя до нього); усвідомлення студентами сутності художньої праці та іiі ролі в формуванні та розвитку майбутньої особистості. Зокрема майбутні педагоги навчаються вирішувати наступні завдання: розвивати у дітей інтерес до вивчення особливостей та властивостей природних та викидних матеріалів, паперу і картону; враховувати властивості різних матеріалів під час створення виробів; формувати у дітей уміння передавати характерні особливості форми, розміру, пропорцій іграшок, співвідношення їхніх частин; розвивати у вихованців почуття кольору, лінії, форми, композиції; формувати у вихлванців уміння виготовляти виріб в певній послідовності; вчити аналізувати створені дітьми іграшки тощо.

Ефективною є організація роботи зі студентами, яка потребує використання знань у іншій, мінливій ситуації. Наприклад, відповідаючи на запитання: “"3 якою метою діти малюють малюнки на інших заняттях, окрім зображувальної діяльності?", студенти зосереджують свою увагу на тому, що це сприяє міцнішому, глибшому засвоєнню знань, оскільки працює інша частина півкуль головного мозку, 
розвиваються психічні процеси (уява, пам'ять, мислення, увага), задіяна дрібна моторика рук, яка активізує розвиток мовлення та $\epsilon$ необхідною умовою підготовки дитини дошкільного віку в подальшому до навчання у школі. Дискутуючи над проблемним запитанням "Чи справедливим $\epsilon$ твердження про те, що продукти дитячої конструктивної діяльності не мають цінності у соціумі?”, студенти усвідомлюють, що продукти дитячої конструктивної діяльності мають цінність у соціумі. Педагог повинен забезпечити їхнє функціонування у вигляді подарунків, сувенірів, елементів оформлення помешкання, інтер'єру дошкільного закладу освіти тощо.

Під час лабораторно-практичних занять студенти опановують найпростіші роботи 3 різними матеріалами. Наприклад, у процесі роботи 3 папером його складають, розрізають, розривають, мнуть, згинають, надрізають, склеюють, приклеюють, наклеюють папір, виготовляють 3 нього різноманітні вироби і надалі моделюють способи художньо-конструктивної діяльності 3 дітьми в навчальній аудиторії. Працюючи над проблемним питанням "Чи доцільно застосовувати ігрові методи та прийоми на заняттях 3 художньої праці?”, майбутні педагоги з’ясовують, що це допомагає створити потрібну для творчості атмосферу, піднімає настрій, активізує до діяльності, надає заняттю відпочинкового арт-терапевтичного характеру тощо.

Вагомим для курсу "Художня праця та основи дизайну" є добір методів, прийомів та засобів задля формування у дітей дошкільного віку художньоконструктивних умінь та навичок (розвиток творчих здібностей вихованців, формування в них технологічних та художньо-продуктивних навичок, самостійності, культури та безпеки художньої праці). Цілеспрямований доцільний вплив педагога на розвиток творчих здібностей дітей $\epsilon$ обов'язковою умовою організації освітнього процесу, що створює позитивний емоційний настрій, спрямовує творчу активність вихованців. Працюючи над запитанням "Чи справедливим $\epsilon$ твердження, що художньо-конструктивна діяльність забезпечує наступність між дошкільним закладом освіти та початковою школою?", студенти зауважують, що структура заняття 3 художньої праці та уроку у першому класі схожі, а види діяльності, матеріали та прилади для означеної діяльності знайомі дітям; характер та атмосфера як заняття в ЗДО та уроку у початковій школі спрямовано на розвиток усіх психічних процесів дитини. Цікавим $\epsilon$ наступне запитання “Як виготовлення конкретного виробу впливає на розвиток особистості дитини?” Працюючи над ним, студенти зауважують, що у дітей розвиваються посидючість, цілеспрямованість, пам'ять увага, мислення, уява, мовлення, удосконалюється дрібна моторика рук тощо.

Результатом оволодіння дитиною різними видами предметної та художньої діяльності $\epsilon$ сформоване емоційно-ціннісне ставлення до процесу та продуктів творчої діяльності, позитивна мотивація досягнень; здатність орієнтуватися в розмаїтті властивостей предметів, розуміти різні способи створення художніх образів, виявляти інтерес до об'єктів, явищ та форм художньо-продуктивної діяльності, а також оволодіння навичками практичної діяльності, культури споживання. При цьому, в процесі підготовки майбутніх педагогів акцент зосереджуємо на діяльності: “(знання, уміння, навички)+ діяльність” [3, с. 18]. Тобто ми застосовуємо таку модель підготовки майбутніх педагогів до художньоконструктивної діяльності з дітьми дошкільного віку, де якість і кількість навчальної інформації у освітньому процесі 3ВО визначається тією діяльністю, яку 
пропонуватимемо дітям. Наприклад, під час опанування теми “Виготовлення виробів у техніці “Оригамі" студенти на конкретному прикладі демонструють, що навчання оригамі відбувається поетапно (показ одного прийому - обов'язкове виконання дітьми; показ другого прийому - i також виконання дітьми). Також студентка демонструє й те, як ретельно дбає про збіг кутів і протилежних сторін під час згинання (“куточки мають зійтись - зустрітися"), а лінії згину слід згладжувати. Надалі, після того, як виріб уже повністю готовий, майбутньому педагогу слід повторити усі прийоми складання та проаналізувати можливі складнощі чи утруднення під час аналогічної роботи з дітьми. Надалі студенти аналізують те, як виготовлення конкретного виробу впливає на повноцінний розвиток дитини: така діяльність формує пізнавальну активність дитини, сприяє розвитку логічного мислення, оскільки дошкільник порівнює, виділяє, узагальнює; формує здатність до експериментування та винахідництва; через активну практичну діяльність діти опановують просторові відносини; розвиваються психічні процеси: мислення, пам'ять, відчуття, сприйняття, дотик; відбувається розвиток дрібної моторики пальців рук;дитина вчиться уважно чути інструкції вихователя, послідовно виконувати практичні дії тощо.

Ми погоджуємося 3 думкою О. Вишневського стосовно того, що "будучи наукою “діяльнісною”, педагогіка мала б реалізувати своє призначення на прикладному рівні” [3, с. 6]. Тому під час підготовки студентів до художньоконструктивної діяльності 3 дітьми, використовуємо міжпредметну інтеграцію: "Театралізована діяльність": (виготовлення масок чи атрибутів для казкових персонажів, створення декорацій до свят); “Фізична культура" (виготовлення атрибутів до фізкультурних розваг, змагань, свят); "Музичне виховання" (виготовлення виробів задля оформлення святкової зали до свят; "Розвиток мовлення" (створення виробів до сюжетів українських народних чи літературних казок) тощо.

При цьому акщентуємо на формуванні у студентів прагнень до постійного пошуку у напрямі оновлення своїх знань, оскільки в епоху "інформаційного вибуху" та мінливості освітнього середовища отримати усі необхідні для успішної педагогічної діяльності з дітьми знання під час навчання в закладі вищої освіти вже неможливо. У майбутній професійній діяльності педагогам потрібно буде самостійно добирати потрібну чи необхідну інформацію.

Висновки та перспективи подальших досліджень. Отож світній процес в закладі вищої освіти слід організовувати так, щоб форми організації навчальнопізнавальної діяльності були адекватними формам засвоюваної майбутньої професійної діяльності. Тому важливого значення слід надавати створенню креативного середовища у освітньому процесі ЗВО під час підготовки студентів до творчої взаємодії з вихованцями: моделюванню форм роботи 3 дітьми, творчій художньо-конструктивній діяльності студентів. Запропонована стаття не вичерпує усіх аспектів порушеної проблеми. Подальших наукових розробок потребують питання обгрунтування організаційно-педагогічних умов підготовки майбутніх педагогів до творчої художньо-конструктивної діяльності з дітьми дошкільного віку.

\section{Література}

1. Борин Г. В. Художньо-естетичний розвиток дітей: напрями удосконалення підготовки майбутніх педагогів до взаємодії з сім'ями вихованців / Г. В. Борин // Освітній простір України. - 2018. - №12. - С. 56-61.

2. Гончаренко С. У. Педагогічні дослідження : методологічні поради молодим науковцям / С. У. Гончаренко. - Київ - Вінниця: ДОВ “Вінниця", 2008. - 278 с. 
3. Вишневський О. Українська освіта на шляху реформ. Актуальні питання сучасної української освіти і змісту виховання Статті. Нариси. Концепції / О. Вишневський. - Дрогобич, 2009. - 72 c.

4. Падалка Г. М. Учитель, музика, діти / Г.М. Падалка - К.: Муз. Україна. 1982. - 144 с.

5. Сотська Г. І. Образотворче мистецтво як засіб розвитку особистості / Г. І. Сотська // Мистецтво у розвитку особистості : монографія / за ред. Н. Г. Ничкало. - Чернівці : Зелена Буковина, 2006 - C. $137-146$

6. Чайка В. М. Підготовка майбутнього вчителя до саморегуляції педагогічної діяльності: монографія / за ред. Г.В. Терещука / В. М. Чайка. - Тернопіль: ТНПУ, 2006. - 275 с.

7. Якса Н. В. Основи педагогічних знань / Н.В. Якса. - Навчальний посібник. - Київ.: Знання, $2007-358 \mathrm{c}$

\section{References}

1. Boryn H. V. Khudozhno-estetychnyi rozvytok ditei: napriamy udoskonalennia pidhotovky maibutnikh pedahohiv do vzaiemodii z simiamy vykhovantsiv / H. V. Boryn // Osvitnii prostir Ukrainy. - 2018. - №12. - S. 56-61.

2. Honcharenko S.U. Pedahohichni doslidzhennia : metodolohichni porady molodym naukovtsiam. / S.U. Honcharenko. - Kyiv - Vinnytsia: DOV "Vinnytsia", 2008. - 278 s.

3. Vyshnevskyi O. Ukrainska osvita na shliakhu reform. Aktualni pytannia suchasnoi ukrainskoi osvity i zmistu vykhovannia Statti. Narysy. Kontseptsii. - Drohobych, 2009. - 72 s.

4. Padalka H.M. Uchytel, muzyka, dity / H.M. Padalka - K.: Muz. Ukraina. 1982. - 144 s.

5. Sotska H.I. Obrazotvorche mystetstvo yak zasib rozvytku osobystosti / H.I. Sotska // Mystetstvo u rozvytku osobystosti : monohrafiia / za red. N.H. Nychkalo. - Chernivtsi : Zelena Bukovyna, 2006. S. $137-146$

6. Chaika V.M. Pidhotovka maibutnoho vchytelia do samorehuliatsii pedahohichnoi diialnosti: monohrafiia / za red. H.V. Tereshchuka /V.M. Chaika. - Ternopil: TNPU, 2006. - $275 \mathrm{~s}$.

7. Iaksa N.V. Osnovy pedahohichnykh znan / N.V. Yaksa. - Navchalnyi posibnyk. - Kyiv.: Znannia, $2007-358 \mathrm{~s}$.

\section{Вікторія Завидович,}

Національна академія Державної Прикордонної служби України імені Б. Хмельницького (м. Хмельницький, Україна)

Victoriia Zavydovych, National Academy of the State Border Guard Service of Ukraine named after Bohdan Khmelnytskyi (Khmelnytskyi, Ukraine) zvv2012@ukr.net

\section{КРИТЕРІЇ, ПОКАЗНИКИ ТА РІВНІ РОЗВИТКУ КОМУНІКАТИВНОЇ КОМПЕТЕНТНОСТІ ОФЩЕРІВ-ПРИКОРДОННИКІВ В УМОВАХ МАГІСТРАТУРИ}

\section{CRITERIA, INDICATORS AND LEVELS OF DEVELOPMENT OF COMMUNICATIVE COMPETENCE OF BORDER GUARDS IN THE MASTER'S CONDITIONS}

Проблема розвитку комунікативної компетентності як основи взаєморозуміння $i$ взаємодії сьогодні набуває все більиой актуальності. Особливі вимоги до володіння означено юкомпетентністю висуваються до офіџерів-прикордонииків. У статті висвітлено та обтрунтовано наукові підходи у з'ясуванні критеріїв, показників і рівнів розвитку досліджуваного феномена. Визначено такі критерій: мотиваційний, когнітивний, діяльнісний, які безпосередньо співвідносяться зі структурними компонентами. Для вказаних критеріїв установлені відповідні показники, ицо їх характеризують, рівні розвитку 